ISSN 1392-3196 / e-ISSN 2335-8947

Zemdirbyste-Agriculture, vol. 105, No. 3 (2018), p. 195-202

DOI 10.13080/z-a.2018.105.025

\title{
The interaction of soil aggregate stability with other soil properties as influenced by manure and nitrogen fertilization
}

\author{
Mihkel ARE ${ }^{1}$, Tanel KAART ${ }^{2}$, Are SELGE ${ }^{1}$, Alar ASTOVER ${ }^{1}$, Endla REINTAM ${ }^{1}$ \\ ${ }^{1}$ Institute of Agricultural and Environmental Sciences, Estonian University of Life Sciences \\ Kreutzwaldi 1, Tartu, Estonia \\ E-mail: mihkelare@gmail.com \\ ${ }^{2}$ Institute of Veterinary Medicine and Animal Sciences, Estonian University of Life Sciences \\ Kreutzwaldi 1, Tartu, Estonia
}

\begin{abstract}
Soil water-stable aggregate (WSA) stability is one of the most important indicators of soil health, because it influences chemical, biological and other physical properties. At the same time, WSA formation, stabilization and degradation are also some of the most complex processes that occur in the soil, making them difficult to fully understand. In particular, there is a lack of research on WSA stability in the Baltic region. To gain a better understanding how aggregation occurs in Estonian pedo-climatic conditions, this study was conducted in 20142015 in a sandy loam Stagnic Luvisol (LV-st) (WRB, 2014). Potato and barley plots were analysed in a three-year crop rotation (potato $\rightarrow$ spring wheat $\rightarrow$ barley) with straw removal. The nitrogen $(\mathrm{N})$ fertilization treatments were $0,40,80,120$ and $160 \mathrm{~kg} \mathrm{ha}^{-1} \mathrm{yr}^{-1} \mathrm{~N}$, both without and with $40 \mathrm{Mg} \mathrm{ha}^{-1}$ fermented cattle farmyard manure (FYM) application prior to potato planting in the previous autumn. WSA stability was determined by Eijkelkamp's wet sieving apparatus from air-dried soil samples of less than $2 \mathrm{~mm}$ in diameter. The study revealed a negative correlation $(r=-0.16)$ between increased $\mathrm{N}$ rates and WSA stability, regardless of FYM applications. Although soil organic carbon ( $\mathrm{SOC}$ ) content increased with additional $\mathrm{N}$ fertilization rates, the reduction in soil acidity $\left(\mathrm{pH}_{\mathrm{KC}}\right)$ levels caused by $\mathrm{N}$ fertilization, most likely repealed the positive SOC content effect on WSA stability. In general, compared with sole $\mathrm{N}$ fertilization, FYM application had a positive effect on WSA stability. However, even though WSA stability did not always increase with FYM applications, it still had a positive effect on bulk density, SOC content and soil acidity levels. Further research is needed in Estonia due to the complexities involved in the soil aggregation process.
\end{abstract}

Key words: barley, farmyard manure, nitrogen fertilizer, potato, soil aggregate stability.

\section{Introduction}

The world population is growing steadily, and crop yields per unit area are rising to meet the increased demand for food. To fulfil this need, increasingly larger amounts of nitrogen fertilizers are being used in many European countries (including Estonia), while farmyard manure applications are slightly decreasing or remaining constant (OECD, 2016). These trends lead to more intensive farming, which puts more pressure on the soil. Soil structural degradation starts when larger aggregates are broken into smaller aggregates. This leads to a reduction in soil porosity and an increase in bulk density, which causes further unfavourable conditions for plant growth. From an agricultural standpoint, the most valuable aggregates are those that are capable of withstanding mechanical wetting stress. Further, aggregate size matters - according to well-known aggregate hierarchy theory, the smaller micro-aggregates $(<0.25 \mathrm{~mm})$ have greater structural strength than macro-aggregates $(>0.25 \mathrm{~mm})$ due to their stronger binding forces, and therefore are less affected by soil management (Liu et al., 2014). Soil water-stable aggregate (WSA) stability is directly influenced by various factors and their interactions; this makes the aggregation process (formation, degradation and stabilization) even more difficult to fully understand (Amézketa, 1999). WSA stability is predominately influenced by the following factors: soil organic carbon (SOC) content, texture, temperature, water content, freeze-thaw conditions, wetting-drying cycles, differences in soil management (e.g., tillage and crop rotation and residue management), acidity levels and calcium carbonate $\left(\mathrm{CaCO}_{3}\right)$ concentrations, root mass, root length and microbial richness. The increased frequency of torrential rain in this pedo-climatic area, could according to Truman et al. (1990) be beneficial for aggregate stability, because elevated initial soil water content makes aggregates more resistant to flowing water

Please use the following format when citing the article:

Are M., Kaart T., Selge A., Astover A., Reintam E. 2018. The interaction of soil aggregate stability with other soil properties as influenced by manure and nitrogen fertilization. Zemdirbyste-Agriculture, 105 (3): 195-202 DOI 10.13080/z-a.2018.105.025 
and rain drop forces. This is due to the reduced rapid release of entrapped air in pores of soil structure (Zaher, Caron, 2008). Although, at the same time, the higher water content makes soil more vulnerable to compaction by increased bulk density due to agricultural farming traffic (Nawaz et al., 2013).

It is a known fact that some factors such as climate and soil texture are inherent and therefore not able to be changed. Different climatic regions have diverse temperatures and precipitation rates which influence the decomposition rate of organic matter and overall soil genesis. However, other properties can be manipulated by tillage, fertilization, crop rotation and acidity neutralization with liming. Even though tillage helps to loosen soil compaction, it also disrupts soil aggregates, roots and fungal hyphens, and decreases SOC content through mineralization. This reduction in binding agents causes a reduction in WSA (Tisdall, Oades, 1982). Both nitrogen fertilization and farmyard manure have been shown to increase SOC content with increased above and below ground biomass production, especially if plant residues are returned to the soil. Various studies have demonstrated that SOC content is the primary influencing factor for WSA stability (Al-Kaisi et al., 2014). Despite having similar effects on SOC content, manure provides additional soil benefits that are not seen with nitrogen fertilizers. Manure has the added benefit of further increasing WSA stability by enriching soil with additional organic matter and plant nutrients, stabilizing soil acidity and increasing microorganism community diversity. Some research even suggests that nitrogen fertilizers may decrease WSA stability (Czachor et al., 2015). With different fertilizers the soil is enriched by cations $\mathrm{Ca}^{2+}, \mathrm{Mg}^{2+}$ and $\mathrm{K}^{+}$from which extensive $\mathrm{K}^{+}$can lead to reduction of soil structure, dispersion of clay particles; especially if $\mathrm{K}^{+}$concentration is higher relative to $\mathrm{Ca}^{2+}$ and $\mathrm{Mg}^{2+}$ concentrations (Rengasamy, Marchuk, 2011).

As mentioned by Ball et al. (2005), different crops like cereals and potato vary by root penetration depth, composition and produced root biomass. This further leads to differences in WSA stability. If crop rotation contains grasses and legumes, the soil structure usually improves due to high root mass and lack of tillage (DuPont et al., 2010). However, because those crops are not profitable in Estonia, cash crop cereals are more frequently preferred in crop rotations. Still according to Kasper et al. (2009), the effects on soil structure can be modified or even erased with tillage through aggregate disturbance. Previous research on WSA stability is not directly comparable due to (i) different pedo-climatic conditions, (ii) lack of a standardized WSA stability determination method and (iii) not many studies that have investigated WSA stability interactions among multiple soil properties. The purpose of this study was to gain knowledge how the soil water-stable aggregation process occurs and interacts with other soil properties in Baltic pedo-climatic conditions. In particular, this study focused on farmyard manure application and different nitrogen fertilization rates in a cereal-rich crop rotation with removed straw.

\section{Materials and methods}

Study site. The long-term IOSDV (Internationaler Organischer Stickstoff-Dauerdüngungs-Versuch) field experiment located near Tartu (N 58 22'19",
E 26 39'53"), Estonia was established in 1989. It belongs to a wider European experiment network and is managed by the Department of Soil Science at the Estonian University of Life Sciences. This study focused on the experimental period of 2014-2015. The soil type, according to the WRB (2014) classification, is a Stagnic Luvisol $(L V-s t)$, and the texture in FAO classification is sandy loam: $57.86 \%$ sand $(>0.063 \mathrm{~mm}), 33.58 \%$ silt $(0.063-0.002 \mathrm{~mm})$ and $8.55 \%$ clay $(<0.002 \mathrm{~mm})$. The field experiment $(45 \times 150 \mathrm{~m})$ was divided into three different fields $(15 \times 150 \mathrm{~m})$, each field with a different crop. The three-year crop rotation included potato (Solanum tuberosum L.), spring wheat (Triticum aestivum L.) and spring barley (Hordeum vulgare L.). Plant residues from cereals had been removed, and lime was applied in year 2000 by dolomite meal $\mathrm{CaMg}\left(\mathrm{CO}_{3}\right)_{2}$ at a rate of $5 \mathrm{Mg} \mathrm{ha}^{-1}$. All of the fields were divided into three strips which received different fertilizer treatments: 1) nitrogen $(\mathrm{N})$ fertilizer: $0\left(\mathrm{~N}_{0}\right), 40\left(\mathrm{~N}_{40}\right), 80\left(\mathrm{~N}_{80}\right), 120$ $\left(\mathrm{N}_{120}\right)$ and $\left.160\left(\mathrm{~N}_{160}\right) \mathrm{kg} \mathrm{ha}^{-1} \mathrm{yr}^{-1} \mathrm{~N}, 2\right)$ nitrogen fertilizer with $40 \mathrm{Mg} \mathrm{ha}^{-1}$ farmyard manure (FYM) and 3 ) a variety of alternative organic fertilizers. The third treatment was excluded from this study. All treatments were in three replications. Ammonium nitrate $\left(\mathrm{NH}_{4} \mathrm{NO}_{3}\right)$ containing $34.4 \% \mathrm{~N}$ was used for nitrogen fertilizer. In early April prior to sowing, all cereal plots with fertilizer levels of $\mathrm{N}_{40}$ and $\mathrm{N}_{80}$ received their full fertilizer quantities. The fertilization rates of $\mathrm{N}_{120}$ and $\mathrm{N}_{160} \mathrm{~kg}$ received $80 \mathrm{~kg} \mathrm{ha}^{-1}$ $\mathrm{yr}^{-1} \mathrm{~N}$ before sowing and the remainder in late May / early June. Regardless of the fertilizer level, potato plots received the total required amount of $\mathrm{NH}_{4} \mathrm{NO}_{3}$ at the time of planting (in both years on $16^{\text {th }}$ May). Fermented cattle farmyard manure was applied at a rate of $40 \mathrm{Mg} \mathrm{ha}^{-1}$ at the end of October only in fields that were to be planted with potato in the following year. A few days after manure spreading, the soil was ploughed at a depth of $25 \mathrm{~cm}$.

Weather conditions. Estonia belongs to a humid continental climatic region. According to the Estonian Environment Agency Weather Station located near Tartu,

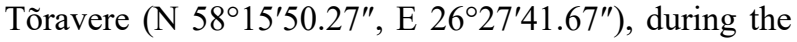
27-year period from 1989 to 2016, the mean annual temperature and precipitation were $6.3^{\circ} \mathrm{C}$ and $672 \mathrm{~mm}$, respectively. The annual variation of mean temperature and precipitation was high. In 2014, the mean temperature $\left(6.9^{\circ} \mathrm{C}\right.$ ) was $0.6^{\circ} \mathrm{C}$, or $9.5 \%$, higher, and the amount of precipitation $(701 \mathrm{~mm}$ ) was $29 \mathrm{~mm}$, or $4.3 \%$, higher than the 27-year-average. Alternatively, the mean temperature in $2015\left(7.5^{\circ} \mathrm{C}\right)$ was $1.2^{\circ} \mathrm{C}$, or $19 \%$, higher, and the amount of precipitation $(622 \mathrm{~mm})$ was $50 \mathrm{~mm}$, or $7.5 \%$, lower than the period average. During harvesting season (September-October) in 2014 and 2015, the precipitation levels were 63 and $76 \mathrm{~mm}$, respectively. Both years were similar, but when compared to 27-year-average $(118 \mathrm{~mm})$, the rainfall was almost twice less.

Soil sampling. Soil samples were collected for laboratory analyses on $15^{\text {th }}$ October, 2014 and $6^{\text {th }}$ October, 2015. Soil samples for measuring dry bulk density were taken using soil sampling cylinders (height $40 \mathrm{~mm}$, internal diameter $53 \mathrm{~mm}$, capacity $88.2026 \mathrm{ml}$ ). Four samples were taken from each plot at a depth of 5-10 cm. Two samples were taken from potato plots at the inside and outside of the furrow to get more equitable results. Loose soil material for analysing soil water-stable aggregate (WSA) stability, soil organic carbon (SOC) content and soil acidity $\left(\mathrm{pH}_{\mathrm{KCl}}\right)$, were randomly collected 
from each plot using a soil probe at a depth of $0-20 \mathrm{~cm}$ and were placed in a zipped plastic bag.

Physical measurements. Bulk density was determined by oven method at $105.5^{\circ} \mathrm{C}$ for $24 \mathrm{~h}$. To ascertain WSA stability, air-dried soil was sifted through a 2-mm sieve. Four replications of $4 \mathrm{~g}$ of soil were added into sieves with a $0.25 \mathrm{~mm}$ mesh size of a wet sieving apparatus ("Eijkelkamp", The Netherlands), which was based on Kemper and Rosenau (1986) concept. Compared to the original method, an exception was made in the concentration of the dispersing water solution. To dissolve organic matter more rapidly, the $0.2 \% \mathrm{NaOH}$ solution concentration was increased to $0.4 \%$. Pipette method was used for determining sand $(>0.0 .63 \mathrm{~mm})$, silt $(0.063-0.002 \mathrm{~mm})$ and clay $(<0.002 \mathrm{~mm})$ particle size distribution.

Chemical analyses. SOC content was measured using the Tyurin method (Vorobeva, 1998). Total nitrogen was measured using the Kjeldahl method (Sáez-Plaza et al., 2013). Soil acidity $\left(\mathrm{pH}_{\mathrm{KCl}}\right)$ was determined using a $1 M$ (mole) potassium chloride $(\mathrm{KCl})(1: 2.5$ - soil: water proportion) solution (Soil Survey Staff, 2014).

Statistical analysis. Full-factorial analysis of variance $(A N O V A)$ was used to test the statistical significance of crop, nitrogen fertilizer, farmyard manure and hydrothermal coefficient and their interaction effects on soil properties (bulk density, WSA stability, soil acidity and SOC content). Additionally, the sample plot was considered as a random factor, because the same plots were shared by barley in 2014 and potato in 2015 . The Tukey HSD (honest significant difference) test was applied for pairwise comparisons of the factors. The significance level was set at 5\%, and all data analysis was performed using software Statistica, version 13.

\section{Results}

The study found weak positive correlations between WSA stability and soil acidity, SOC content, loam and clay content, while weak negative correlations between total nitrogen and sand content, from which statistically significant was only correlation between WSA stability and SOC content (Table 1). Additional correlations were calculated between bulk density and gravimetric water content which showed a significant weak negative correlation $(r=-0.20, p=0.03)$ and between bulk density and volumetric water content, which showed a non-significant weak positive correlation $(r=+0.13, p=0.15)$

Table 1. Correlations with soil aggregate stability

\begin{tabular}{lc}
\hline \multicolumn{1}{c}{ Soil properties } & Correlation coefficient $(r)$ \\
\hline Bulk density & -0.11 \\
Soil acidity $\left(\mathrm{pH}_{\mathrm{KCl}}\right)$ & +0.15 \\
Soil organic carbon (SOC) & $+0.22 *$ \\
Total nitrogen $\%$ & -0.16 \\
Sand $(>0.063 \mathrm{~mm}) \%$ & -0.13 \\
Silt $(0.063-0.002 \mathrm{~mm}) \%$ & +0.08 \\
Clay $(<0.002 \mathrm{~mm}) \%$ & +0.17 \\
\hline
\end{tabular}

* - significant at $p<0.05$

The ANOVA showed that nitrogen fertilization and farmyard manure both had a significant impact on all investigated soil properties: WSA stability, bulk density, soil acidity and SOC content (Table 2). From the soil tillage viewpoint, one of the greatest differences between potato and barley cultivation was that potato

Table 2. The effects of different factors on soil properties

\begin{tabular}{|c|c|c|c|c|}
\hline Factor & $\begin{array}{l}\text { Water-stable aggregate } \\
\text { (WSA) stability }\end{array}$ & $\begin{array}{c}\text { Bulk } \\
\text { density }\end{array}$ & $\begin{array}{c}\text { Soil acidity } \\
\left(\mathrm{pH}_{\mathrm{KC}}\right)\end{array}$ & $\begin{array}{l}\text { Soil organic carbon } \\
\text { (SOC) content }\end{array}$ \\
\hline Crop & $\begin{array}{c}\mathrm{F}_{1.440}=3.40 \\
p=0.066\end{array}$ & $\begin{array}{c}\mathrm{F}_{1.440}=140.90 \\
p<0.001^{*}\end{array}$ & $\begin{array}{l}\mathrm{F}_{1.80}=8.70 \\
p=0.004 *\end{array}$ & $\begin{array}{c}\mathrm{F}_{1.80}=0.01 \\
p=0.920\end{array}$ \\
\hline Nitrogen $(\mathrm{N})$ & $\begin{array}{l}\mathrm{F}_{4.440}=9.0 \\
p<0.001 *\end{array}$ & $\begin{array}{l}\mathrm{F}_{4.440}=2.76 \\
p=0.028^{*}\end{array}$ & $\begin{array}{c}\mathrm{F}_{4.80}=14.17 \\
p<0.001^{*}\end{array}$ & $\begin{array}{l}\mathrm{F}_{4.80}=6.30 \\
p<0.001^{*}\end{array}$ \\
\hline Farmyard manure (FYM) & $\begin{array}{c}\mathrm{F}_{1.440}=91.40 \\
p<0.001^{*}\end{array}$ & $\begin{array}{c}\mathrm{F}_{1.440}=53.13 \\
p<0.001^{*}\end{array}$ & $\begin{array}{c}\mathrm{F}_{1.80}=105.96 \\
p<0.001^{*}\end{array}$ & $\begin{array}{c}\mathrm{F}_{1.80}=437.29 \\
p<0.001^{*}\end{array}$ \\
\hline Hydrothermal coefficient (HTC) & $\begin{array}{c}\mathrm{F}_{1.440}=110.07 \\
p<0.001^{*}\end{array}$ & $\begin{array}{c}\mathrm{F}_{1.440}=1.46 \\
p=0.227\end{array}$ & $\begin{array}{c}\mathrm{F}_{1.80}=18.36 \\
p<0.001 \%\end{array}$ & $\begin{array}{c}\mathrm{F}_{1.80}=3.64, \\
p=0.060\end{array}$ \\
\hline Crop $\times \mathrm{N}$ & $\begin{array}{c}\mathrm{F}_{4.440}=1.68 \\
p=0.154\end{array}$ & $\begin{array}{c}\mathrm{F}_{4.440}=3.35 \\
p=0.010^{*}\end{array}$ & $\begin{array}{c}\mathrm{F}_{4.80}=0.55 \\
p=0.702\end{array}$ & $\begin{array}{c}\mathrm{F}_{4.80}=0.08 \\
p=0.989\end{array}$ \\
\hline Crop $\times$ FYM & $\begin{array}{c}\mathrm{F}_{1.440}=7.43 \\
p=0.007^{*}\end{array}$ & $\begin{array}{c}\mathrm{F}_{1.440}=1.07 \\
p=0.302\end{array}$ & $\begin{array}{c}\mathrm{F}_{1.80}=0.52 \\
p=0.472\end{array}$ & $\begin{array}{c}\mathrm{F}_{1.80}=1.90 \\
p=0.172\end{array}$ \\
\hline $\mathrm{N} \times \mathrm{FYM}$ & $\begin{array}{c}\mathrm{F}_{4.440}=3.37 \\
p=0.010^{*}\end{array}$ & $\begin{array}{c}\mathrm{F}_{4.440}=3.27 \\
p=0.012 *\end{array}$ & $\begin{array}{c}\mathrm{F}_{4.80}=1.26 \\
p=0.292\end{array}$ & $\begin{array}{c}\mathrm{F}_{4.80}=0.24 \\
p=0.917\end{array}$ \\
\hline Crop $\times$ HTC & $\begin{array}{c}\mathrm{F}_{1.440}=156.15 \\
p<0.001^{*}\end{array}$ & $\begin{array}{c}\mathrm{F}_{1.440}=1.61 \\
p=0.205\end{array}$ & $\begin{array}{c}\mathrm{F}_{1.80}=36.78 \\
p<0.001^{*}\end{array}$ & $\begin{array}{c}\mathrm{F}_{1.80}=1.08 \\
p=0.302\end{array}$ \\
\hline $\mathrm{FYM} \times \mathrm{HTC}$ & $\begin{array}{c}\mathrm{F}_{1.440}=36.26 \\
p<0.001 *\end{array}$ & $\begin{array}{c}\mathrm{F}_{1.440}=0.82 \\
p=0.366\end{array}$ & $\begin{array}{c}\mathrm{F}_{1.80}=10.06 \\
p=0.002 *\end{array}$ & $\begin{array}{c}\mathrm{F}_{1.80}=0.26 \\
p=0.613\end{array}$ \\
\hline Crop $\times \mathrm{N} \times$ HTC & $\begin{array}{c}\mathrm{F}_{4.440}=0.31 \\
p=0.872\end{array}$ & $\begin{array}{c}\mathrm{F}_{4.440}=2.43 \\
p=0.047^{*}\end{array}$ & $\begin{array}{c}\mathrm{F}_{4.80}=0.07 \\
p=0.990\end{array}$ & $\begin{array}{l}\mathrm{F}_{4.80}=2.52 \\
p=0.047^{*}\end{array}$ \\
\hline Crop $\times$ FYM $\times$ HTC & $\begin{array}{c}\mathrm{F}_{1.440}=4.42, \\
p=0.036^{*}\end{array}$ & $\begin{array}{c}\mathrm{F}_{1.440}=13.95 \\
p<0.001^{*}\end{array}$ & $\begin{array}{l}\mathrm{F}_{1.80}=6.27 \\
p=0.014 *\end{array}$ & $\begin{array}{c}\mathrm{F}_{1.80}=3.15 \\
p=0.080\end{array}$ \\
\hline $\mathrm{Crop} \times \mathrm{N} \times \mathrm{FYM} \times \mathrm{HTC}$ & $\begin{array}{c}\mathrm{F}_{4.440}=4.03 \\
p=0.003^{*}\end{array}$ & $\begin{array}{c}\mathrm{F}_{4.440}=0.44 \\
p=0.779\end{array}$ & $\begin{array}{c}\mathrm{F}_{4.80}=0.35 \\
p=0.844\end{array}$ & $\begin{array}{c}\mathrm{F}_{4.80}=0.25, \\
p=0.911\end{array}$ \\
\hline
\end{tabular}


needed more intensive tillage, which helped to loosen the soil. Therefore, the difference in crops can also be viewed as difference in tillage intensity. While crop had a statistically significant effect on the impact of bulk density and soil acidity, on WSA stability $(p=0.066)$, the effect was near the threshold level $(p<0.05)$ of significance. The results revealed that SOC content was not affected by crops $(p=0.92)$. The annual variation or hydrothermal coefficient (HTC) was significant for WSA stability and soil acidity, and had an influence on SOC content $(p=0.60)$. WSA stability was significantly affected by six combinations in which at least two factors were involved, while SOC content was only significantly affected by the interactions of crops, nitrogen and manure fertilization. The interaction of crops, manure and HTC had significant effect on all investigated soil properties, except SOC content. These results confirmed that soil aggregation is a complex process and is influenced by various factors and their combinations. However, SOC content is mainly only affected by fertilization.

Soil acidity $\left(\boldsymbol{p} \boldsymbol{H}_{K C}\right)$. The results revealed that higher $\mathrm{N}$ application rates were associated with acidic soil (Table 3). However, with the exception of potato in both years with sole $\mathrm{N}$ fertilizer treatments, the acidification effect was not considered statistically significant. However, the drop in soil acidity levels due to high $\mathrm{N}$ application was less marked with the addition of FYM. The study also revealed that soil acidity increased if FYM was used, but not enough to be considered statistically significantly, except in barley in 2015. With the addition of FYM, the soil acidity increased on average from 5.86 to 6.17 , which was a $5.3 \%$ improvement. In general, the soil acidity was low enough throughout the study where liming would be beneficial, especially in $\mathrm{N}$ fertilizer treatments.

Bulk density. Plots that were fertilized solely with $\mathrm{N}$ had a higher bulk density than those treated with FYM (Table 3). FYM application caused a statistically significant decrease in bulk density in all $160 \mathrm{~kg} \mathrm{ha}^{-1} \mathrm{~N}$ treatments, except in potato in 2015 . The results of the FYM treatments also demonstrated that higher added $\mathrm{N}$ rates corresponded with lower bulk density. This was especially notable in 2015 in barley FYM treatments, where $160 \mathrm{~kg} \mathrm{ha}^{-1} \mathrm{~N}$ fertilization caused significantly lower bulk density than control and $40 \mathrm{~kg} \mathrm{ha}^{-1} \mathrm{~N}$. The two year average results revealed that in potato treatments bulk density $\left(1.47 \mathrm{Mg} \mathrm{m}^{-3}\right)$ was lower than in barley treatments $\left(1.59 \mathrm{Mg} \mathrm{m}^{-3}\right)$ due to more intensive tillage.

Table 3. Soil properties depending on nitrogen fertilization rate $\left(\mathrm{N}_{0}-\mathrm{N}_{160}\right)$, farmyard manure, year and crop (potato or barley)

\begin{tabular}{|c|c|c|c|c|c|c|c|}
\hline \multirow{2}{*}{ Crop } & \multirow{2}{*}{ Year } & \multirow{2}{*}{ FYM } & \multicolumn{5}{|c|}{ Nitrogen $\mathrm{kg} \mathrm{ha}^{-1} \mathrm{yr}^{-1}$} \\
\hline & & & $\mathrm{N}_{0}$ & $\mathrm{~N}_{40}$ & $\mathrm{~N}_{80}$ & $\mathrm{~N}_{120}$ & $\mathrm{~N}_{160}$ \\
\hline \multicolumn{8}{|c|}{ Bulk density $\mathrm{Mg} \mathrm{m}^{-3}$} \\
\hline \multirow{4}{*}{ Barley } & \multirow{2}{*}{2014} & FYM- & $1.60 \pm 0.028$ & $1.60 \pm 0.018$ & $1.62 \pm 0.012$ & $1.58 \pm 0.015$ & $1.61 \mathrm{a} \pm 0.017$ \\
\hline & & FYM+ & $1.58 \pm 0.008$ & $1.56 \pm 0.034$ & $1.54 \pm 0.018$ & $1.54 \pm 0.015$ & $1.52 \mathrm{~b} \pm 0.020$ \\
\hline & \multirow{2}{*}{2015} & FYM- & $1.73 \pm 0.022$ & $1.67 \pm 0.015$ & $1.67 \mathrm{a} \pm 0.018$ & $1.60 \pm 0.027$ & $1.61 \mathrm{a} \pm 0.031$ \\
\hline & & FYM+ & $1.62 \mathrm{~A} \pm 0.025$ & $1.63 \mathrm{~A} \pm 0.016$ & $1.53 \mathrm{ABb} \pm 0.050$ & $1.51 \mathrm{AB} \pm 0.033$ & $1.45 \mathrm{Bb} \pm 0.037$ \\
\hline \multirow{4}{*}{ Potato } & \multirow{2}{*}{2014} & FYM- & $1.45 \pm 0.033$ & $1.54 \pm 0.035$ & $1.55 \pm 0.044$ & $1.52 \pm 0.046$ & $1.57 \mathrm{a} \pm 0.045$ \\
\hline & & FYM+ & $1.44 \pm 0.036$ & $1.46 \pm 0.049$ & $1.44 \pm 0.039$ & $1.35 \pm 0.031$ & $1.39 \mathrm{~b} \pm 0.029$ \\
\hline & \multirow{2}{*}{2015} & FYM- & $1.46 \pm 0.052$ & $1.45 \pm 0.035$ & $1.49 \pm 0.044$ & $1.48 \pm 0.037$ & $1.51 \pm 0.025$ \\
\hline & & FYM+ & $1.47 \pm 0.026$ & $1.48 \pm 0.025$ & $1.43 \pm 0.031$ & $1.48 \pm 0.031$ & $1.45 \pm 0.026$ \\
\hline \multicolumn{8}{|c|}{ Soil acidity $\left(\mathrm{pH}_{\mathrm{KCl}}\right)$} \\
\hline \multirow{4}{*}{ Barley } & \multirow{2}{*}{2014} & FYM- & $6.03 \pm 0.067$ & $5.93 \pm 0.120$ & $5.83 \pm 0.033$ & $5.67 \pm 0.088$ & $5.67 \pm 0.133$ \\
\hline & & FYM+ & $6.03 \pm 0.176$ & $6.10 \pm 0.153$ & $5.97 \pm 0.088$ & $5.93 \pm 0.067$ & $5.90 \pm 0.100$ \\
\hline & \multirow{2}{*}{2015} & FYM- & $6.13 \mathrm{a} \pm 0.067$ & $6.00 \mathrm{a} \pm 0.100$ & $6.00 \mathrm{a} \pm 0.115$ & $5.87 \mathrm{a} \pm 0.088$ & $5.83 \mathrm{a} \pm 0.088$ \\
\hline & & FYM+ & $6.57 \mathrm{~b} \pm 0.033$ & $6.53 \mathrm{~b} \pm 0.067$ & $6.43 b \pm 0.067$ & $6.33 b \pm 0.067$ & $6.47 b \pm 0.088$ \\
\hline \multirow{4}{*}{ Potato } & \multirow{2}{*}{2014} & FYM- & $6.10 \mathrm{~A} \pm 0.153$ & $5.97 \mathrm{AB} \pm 0.033$ & $5.87 \mathrm{AB} \pm 0.088$ & $5.73 \mathrm{AB} \pm 0.088$ & $5.67 \mathrm{~B} \pm 0.033$ \\
\hline & & FYM+ & $6.27 \pm 0.033$ & $6.23 \pm 0.033$ & $6.20 \pm 0.058$ & $6.03 \pm 0.088$ & $5.93 \pm 0.067$ \\
\hline & \multirow{2}{*}{2015} & FYM- & $6.07 \mathrm{~A} \pm 0.067$ & $5.87 \mathrm{AB} \pm 0.133$ & $5.83 \mathrm{AB} \pm 0.033$ & $5.53 \mathrm{~B} \pm 0.145$ & $5.67 \mathrm{AB} \pm 0.133$ \\
\hline & & FYM+ & $6.23 \pm 0.120$ & $6.10 \pm 0.100$ & $6.13 \pm 0.088$ & $6.00 \pm 0.100$ & $6.03 \pm 0.088$ \\
\hline \multicolumn{8}{|c|}{ Soil organic carbon $\%$} \\
\hline \multirow{4}{*}{ Barley } & \multirow{2}{*}{2014} & FYM- & $0.99 \mathrm{a} \pm 0.026$ & $0.99 \mathrm{a} \pm 0.055$ & $1.00 \mathrm{a} \pm 0.048$ & $1.01 \mathrm{a} \pm 0.015$ & $1.01 \mathrm{a} \pm 0.018$ \\
\hline & & FYM+ & $1.24 \mathrm{~b} \pm 0.029$ & $1.28 \mathrm{~b} \pm 0.082$ & $1.24 \mathrm{~b} \pm 0.036$ & $1.24 \mathrm{~b} \pm 0.029$ & $1.29 \mathrm{~b} \pm 0.026$ \\
\hline & \multirow{2}{*}{2015} & FYM- & $0.93 \mathrm{a} \pm 0.041$ & $0.97 \mathrm{a} \pm 0.016$ & $1.02 \mathrm{a} \pm 0.045$ & $1.10 \mathrm{a} \pm 0.018$ & $1.03 \mathrm{a} \pm 0.024$ \\
\hline & & FYM+ & $1.24 \mathrm{~A} \mathrm{~b} \pm 0.039$ & $1.24 \mathrm{Ab} \pm 0.072$ & $1.35 \mathrm{ABb} \pm 0.026$ & $1.44 \mathrm{Bb} \pm 0.026$ & $1.35 \mathrm{ABb} \pm 0.018$ \\
\hline \multirow{4}{*}{ Potato } & \multirow{2}{*}{2014} & FYM- & $0.95 \mathrm{a} \pm 0.017$ & $1.00 \mathrm{a} \pm 0.014$ & $1.05 \mathrm{a} \pm 0.064$ & $1.05 \mathrm{a} \pm 0.030$ & $0.99 \mathrm{a} \pm 0.024$ \\
\hline & & FYM+ & $1.21 \mathrm{~b} \pm 0.079$ & $1.24 \mathrm{~b} \pm 0.082$ & $1.30 \mathrm{~b} \pm 0.045$ & $1.32 \mathrm{~b} \pm 0.047$ & $1.30 \mathrm{~b} \pm 0.008$ \\
\hline & \multirow{2}{*}{2015} & FYM- & $1.01 \mathrm{a} \pm 0.040$ & $1.01 \mathrm{a} \pm 0.041$ & $1.05 \mathrm{a} \pm 0.037$ & $1.05 \mathrm{a} \pm 0.014$ & $1.06 \mathrm{a} \pm 0.019$ \\
\hline & & FYM+ & $1.24 \mathrm{~b} \pm 0.013$ & $1.24 \mathrm{~b} \pm 0.062$ & $1.25 \mathrm{~b} \pm 0.041$ & $1.31 \mathrm{~b} \pm 0.030$ & $1.30 \mathrm{~b} \pm 0.024$ \\
\hline
\end{tabular}

Notes. FYM - without (FYM-) or with (FYM+) farmyard manure; standard error indicates dispersion of the mean. Means without a common capital letter in the same row and means with different lowercase letters in the same column within the same year and crop are significantly different $(p<0.05$, Tukey test); means without small and/or capital letters are not different among described groups. 
Soil organic carbon (SOC) content. The study revealed that in both 2014 and 2015, the use of FYM had a significant positive impact on the SOC content in both crops (Table 3) . On average, the SOC content in FYM treatments $(1.28 \%)$ was higher than in sole $\mathrm{N}$ fertilized treatments $(1.01 \%)$. The results revealed that higher quantities of $\mathrm{N}$ without and with FYM application generally increased the SOC content, but not enough to be considered statistically significant with Tukey's HSD test. An exception was found in barley with FYM treatments and $120 \mathrm{~kg} \mathrm{ha}^{-1} \mathrm{~N}$ in 2015, where SOC content significantly differed from the plots without FYM and with $40 \mathrm{~kg} \mathrm{ha}^{-1} \mathrm{~N}$ fertilization.
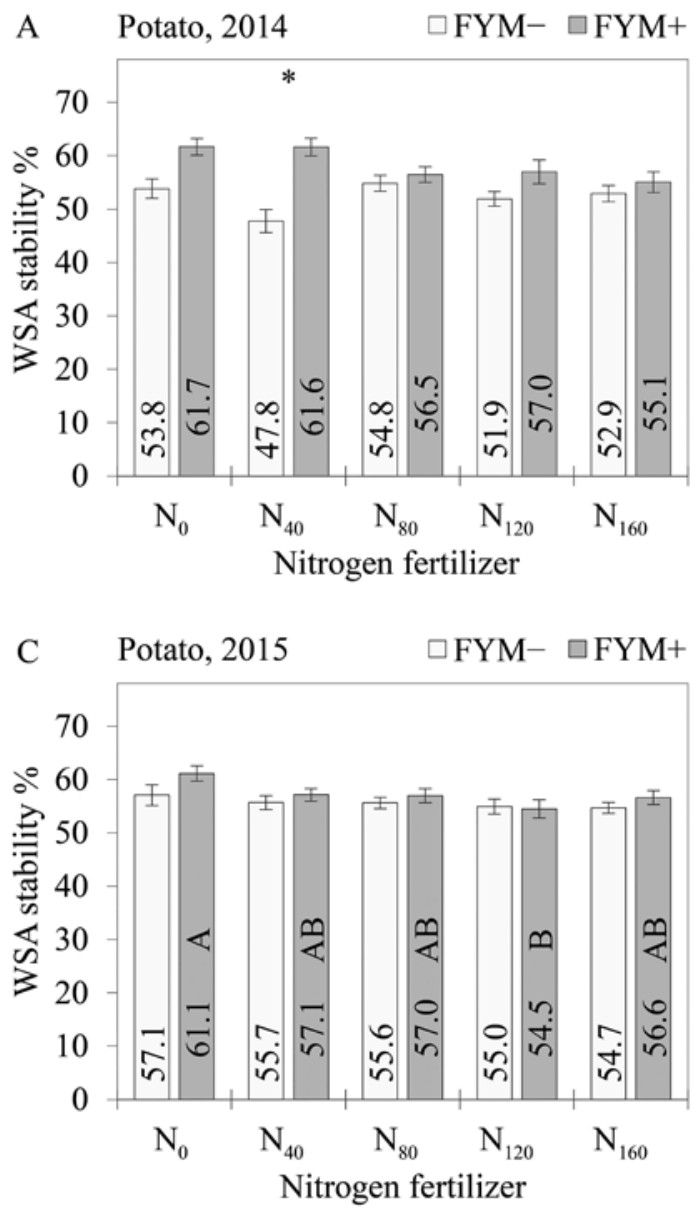

Soil water-stable aggregate (WSA) stability. As previously shown by the analysis of variance, WSA stability was affected by many factors and their combinations (Table 2). A more detailed analysis revealed that in general increased $\mathrm{N}$ rates were associated with decreased WSA stability, being statistically significant in 2015 with FYM application in potato (not for $\mathrm{N}_{160}$ ) and in barley treatments (Fig.). The drop in WSA stability was higher in FYM treatments. However, WSA stability values with FYM application in many cases were higher than those with only $\mathrm{N}$ fertilization. The study also revealed that in 2014, WSA stability values in barley treatments were higher than those in potato treatments; but in 2015 the results were the opposite.
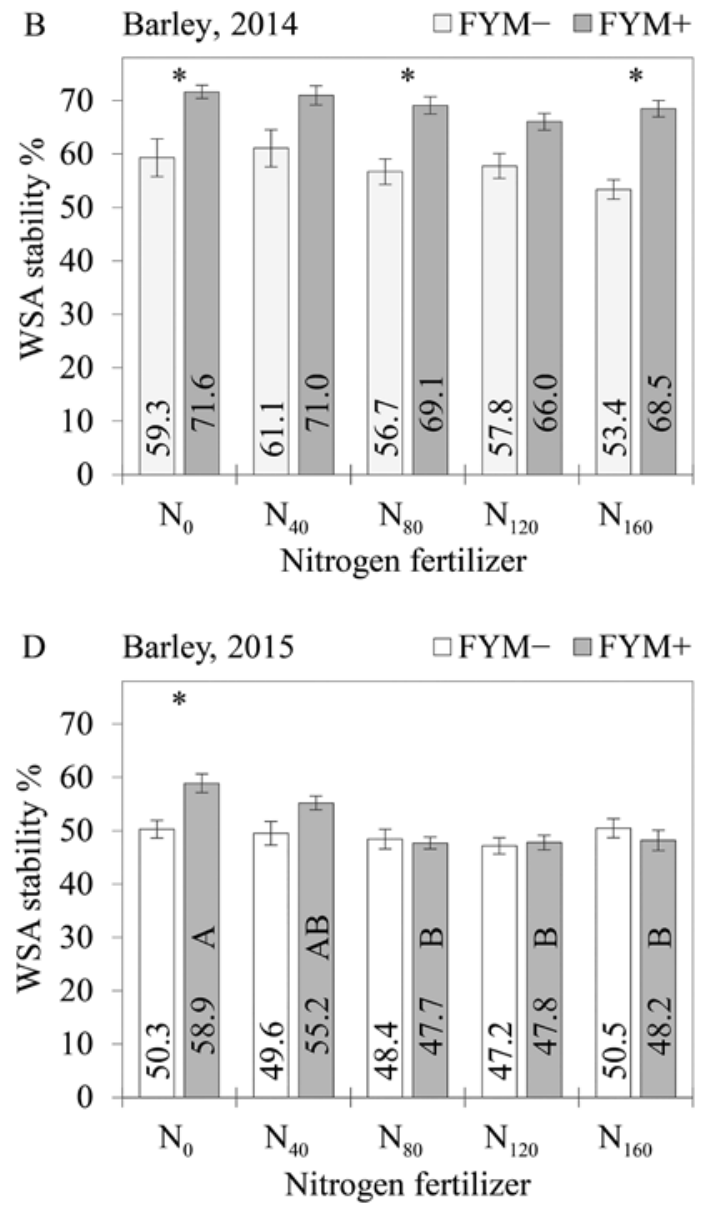

Note. FYM - without (FYM-) or with (FYM+) farmyard manure; stars denote nitrogen fertilizer groups in the same year and crop with statistically significant differences between FYM- and FYM+, nitrogen fertilizer groups without common capital letter are significantly different ( $p<0.05$, Tukey test); means without stars and/or capital letters are not significantly different among the described groups; bars denote standard error of the mean.

Figure. Soil water-stable aggregate (WSA) stability by fertilization rate $\left(\mathrm{N}_{0}-\mathrm{N}_{160}\right)$, farmyard manure, year and crop (potato or barley)

\section{Discussion}

The high annual variability of WSA stability found in this study was most likely caused by the differences in wetting-drying cycles, root development during the growth period and freeze-thaw cycles between the winters. With wetting, air that was entrapped inside the pores of aggregates was rapidly released, which resulted in the collapse of weaker macro-aggregates (Czachor et al., 2015). Additionally, because drying does not occur evenly across the structure, cracks may have developed (Tang et al., 2016), shearing the aggregates apart. If those wetting-drying cycles occur repeatedly, the WSA stability decreases. During the winter freezing period, water expands and tears apart the soil structure. On the one hand, this reduces bulk density by temporarily creating pores, but on the other hand, it also weakens soil structure by reducing WSA stability. Damage is greatest with high moisture content during freezing and increased number of freeze-thaw cycles (Wang et al., 2012). In addition, the daily weather effect cannot be underestimated, because temperature and moisture both 
influence microbial decomposition (Suseela et al., 2012), which could increase the mineralization of organic matter and reduce SOC content (Semenov et al., 2014). This could further decrease the stability of WSA.

In this study, the increase in SOC content due to higher $\mathrm{N}$ rates was likely caused by an increased below ground root mass and above ground biomass with plant residues in potato and cereals. However, it should be noted that the effects of many processes that took place during the study period 2014-2015, were also caused by the long-term experiment as a whole, because many, especially SOC content related processes in soil do not happen immediately. Earlier studies have shown that higher fertilization rates also increased root biomass, especially in the top $20 \mathrm{~cm}$ of soil in similar soil and climatic conditions (Reintam et al., 2005). The crops in this study did not affect SOC content likely due to the crop rotation, which moderated the effects of individual crop. Even though the straw of barley and spring wheat was removed during crop rotation, straw stubble of $\sim 10 \mathrm{~cm}$ was still left on the ground after harvest which could have affected the SOC content pool.

WSA stability was reduced in higher nitrogen fertilizer treatments with cultivation, regardless of FYM application. This could be due to the increase in soil acidity and the subsequent effects on soil microorganisms. The added $\mathrm{N}$ fertilizer is considered an acid, and as such the application of $\mathrm{N}$ fertilizers reduced the soil acidity level due to nitrification of $\mathrm{NH}_{4}^{+}$ in which $\mathrm{H}^{+}$is released into soil (Bouman et al., 1995). Earlier studies have shown that increased $\mathrm{N}$ fertilizer applications reduce the fungal biomass (Bradley et al., 2006), probably because $\mathrm{N}$ fertilization may alter the cost-benefit balance in mycorrhizal symbioses, and that arbuscular mycorrhizal fungi may be less beneficial to plants in $\mathrm{N}$ fertilized soil (Corkidi et al., 2002). If those important temporary organic binding agents are disrupted, the macro-aggregates could become less stable (Tang et al., 2011). Another possibility could be that although extensive nitrogen fertilization increases SOC content, it also reduces root biomass and length; from a macro-aggregate stability stand-point, this could have a far greater effect than SOC content (Jung et al., 2011). Additionally, if the soil acidity level was too low it likely inhibited root development, meaning less polysaccharides (aggregate binding agents) were released into soil (Tisdall, Oades, 1982). Further, it is possible that higher fertilization rates led to increased yields and a faster depletion of $\mathrm{Ca}^{+2}$ and $\mathrm{Mg}^{+2}$ from the soil. Both of those ions play an important role in forming aggregates through the flocculation of clay particles (Rengasamy, Marchuk, 2011). In this study, the soil acidity levels in some plots were below optimum level, therefore in those cases, liming could increase WSA stability. The average $\mathrm{Ca}^{+2}$ and $\mathrm{Mg}^{+2}$ contents in soil, based on the Mehlich 3 method, were 1020 and $33 \mathrm{mg} \mathrm{kg}^{-1}$, respectively. Even if the soil acidity level is within normal range, liming in Estonian soils is necessary if $\mathrm{Ca}^{+2}$ content is $<1500 \mathrm{mg} \mathrm{kg}^{-1}$.

This study found that the application of FYM had various positive effects on the investigated soil properties. FYM application increased the SOC content and decreased the bulk density by adding organic matter. The decrease in bulk density was probably caused by the addition of low density material into more dense soil fractions, based on assumptions by Haynes and Naidu (1998). Also the bulk density could have been temporarily reduced after tillage by increasing porosity
(Jirků et al., 2013). However, tillage also reduces macroaggregates to micro-aggregates (Sheehy et al., 2015), and in the long-term, tillage leads to a decrease in SOC content due to increased decomposition rate of organic matter (Ortas et al., 2013). This decrease in SOC content could further reduce WSA stability, which could make the soil more vulnerable to compaction. This could be the reason for the lower soil structural stability under potato. The higher soil acidity levels found in FYM treatments compared with $\mathrm{N}$ fertilization-only treatments could be due to the $\mathrm{CaCO}_{3}$ in FYM from cattle feed rations. This could have had a liming effect that increased soil acidity levels (Chu et al., 2017) and reduced the acidification caused by nitrogen fertilizer application. It is known that FYM application increases microbial activity and hydrophobic properties, which enhances WSA stability, but the interaction between WSA stability and FYM application was more complicated in the current study.

Despite the positive effects of FYM application on WSA stability and other soil properties reported in other studies (Bottinelli et al., 2017), FYM application do not always increase the WSA stability and could even cause a reduction in aggregate stability, as was found both in this study and by Sánchez de Cima et al. (2016). Our results revealed that in year 2015, in general, WSA stability did not significantly differ between FYM and non-FYM treatments. In three cases on non-FYM treatments, the WSA stability was even slightly higher. There could be many reasons for that result. First, the previously mentioned factors that could cause seasonal changes in WSA stability could affect FYM treatments somewhat differently. However, this result was most likely caused by the combination of high sand (57.9\%) and low SOC $(1.15 \%)$ contents in FYM treatments, and possible differences in FYM composition. In addition to the findings found in this study, it has been found that soil structure is less stable in sandy textures compared with those with higher clay content (Dimoyiannis, 2012) due to the lower flocculation effect of clay particles (Haynes, Naidu, 1998). In addition, according to Le Bissonnais and Arrouays (1997), if SOC content is below 1.5-2.0\%, an invariable aggregate stability is no longer sustained. Therefore, the high sand and low SOC contents found in this experiment could have created conditions where tillage and vehicular compaction during harvest may have cancelled out the benefits of manure application. Further, FYM composition is not homogenous; different components have various decomposition rates and therefore affect WSA stability differently (Leelamanie, Liyanage, 2016). Straw-rich manure has more lignin, which leads to a slower decomposing rate. Therefore, it could be possible that the manure used in barley plots in 2015 had more straw and therefore more slowly decomposing lignin compared to the manure in 2014. The presence of excessive monovalent $\mathrm{Na}^{+}$and $\mathrm{K}^{+}$ cations could have had an effect as well due to difference in FYM composition (Rengasamy, Marchuk, 2011). Sánchez de Cima et al. (2016) suggest that if manure contains enough $\mathrm{Na}^{+}$cations, it could counteract the other benefits of manure. This could also be the case with nitrogen fertilizers due to the presence of $\mathrm{NH}_{4}^{+}$(Bouman et al., 1995); if manure contains high concentrations of $\mathrm{NH}_{4}^{+}$, it could lead to a decrease in WSA stability due to its clay dispersing property similar to $\mathrm{Na}^{+}$(Haynes, Naidu, 1998; Rengasamy, Marchuk, 2011). However, because the 2014 barley and 2015 potato had similar WSA stability values in $\mathrm{N}$ treatments and shared the same plots, it cannot be ruled out that the soil within the 
experimental field had variations in its moisture regime, texture and $\mathrm{Na}^{+}$concentration, which together could alter the WSA stability. Overall the high variability of WSA stability was not unique to this study (Algayer et al., 2014). However, because aggregation is a very complex process, the exact reasons for the results are difficult to define, and further investigations are needed.

\section{Conclusions}

1. Increased nitrogen $(\mathrm{N})$ fertilization rates decreased soil water-stable aggregate (WSA) stability, regardless of cattle farmyard manure (FYM) applications.

2. The use of FYM did not repeal the negative effects of increased $\mathrm{N}$ fertilization rates on WSA stability. Nevertheless, FYM application still enhanced WSA stability and had a positive effect on bulk density, soil organic carbon (SOC) content and soil acidity $\left(\mathrm{pH}_{\mathrm{KC}}\right)$ level. Therefore, regular FYM applications are beneficial for various soil properties.

3. Although SOC content increased with $\mathrm{N}$ fertilizer rates, the soil acidification due to increased $\mathrm{N}$ fertilizer applications most likely cancelled out the positive effects of increased SOC content on WSA stability.

\section{Acknowledgements}

This study was supported by the H2020 project iSQAPER-635750. The authors are also grateful to Avo Toomsoo, Enn Leedu and Triin Teesalu for their longterm dedication to the experiment.

Received 21092017

Accepted 23032018

\section{References}

1. Algayer B., Le Bissonnais Y., Darboux F. 2014. Shortterm dynamics of soil aggregate stability in the field. Soil Science Society of America Journal, 78 (4): 1168-1176. https://doi.org/10.2136/sssaj2014.01.0009

2. Al-Kaisi M. M., Douelle A., Kwaw-Mensah D. 2014. Soil microaggregate and macroaggregate decay over time and soil carbon change as influenced by different tillage systems. Journal of Soil and Water Conservation Society, 69 (6): 574-580. https://doi.org/10.2489/jswc.69.6.574

3. Amézketa E. 1999. Soil aggregate stability: a review. Journal of Sustainable Agriculture, 14 (2-3): 83-151. https://doi.org/10.1300/J064v14n02_08

4. Ball B. C., Bingham I., Rees R. M., Watson, C. A., Litterick A. 2005. The role of crop rotations in determining soil structure and crop growth conditions. Canadian Journal of Soil Science, 85 (5): 557-577. https://doi.org/10.4141/S04-078

5. Bottinelli N., Angers D. A., Hallaire V., Michot D., Le Guillou C., Cluzeau D., Heddadj D., MenasseriAubry S. 2017. Tillage and fertilization practices affect soil aggregate stability in a Humic Cambisol of Northwest France. Soil and Tillage Research, 170: 14-17. https://doi.org/10.1016/j.still.2017.02.008

6. Bouman O. T., Curtin D., Campbell C. A., Biederbeck V. O., Ukrainetz H. 1995. Soil acidification from long-term use of anhydrous ammonia and urea. Soil Science Society of America Journal, 59 (5): 1488-1494. https://doi.org/10.2136/sssaj1995.03615995005900050039x

7. Bradley K., Drijber R. A., Knops J. 2006. Increased N availability in grassland soils modifies their microbial communities and decreases the abundance of arbuscular mycorrhizal fungi. Soil Biology and Biochemistry, 38 (7) 1583-1595. https://doi.org/10.1016/j.soilbio.2005.11.011
8. Chu Q., Sha Z., Osaki M., Watanabe T. 2017. Contrasting effects of cattle manure applications and root-induced changes on heavy metal dynamics in the rhizosphere of soybean in an acidic Haplic Fluvisol: a chronological pot experiment. Journal of Agricultural and Food Chemistry, 65 (15): 3085-3095. https://doi.org/10.1021/acs.jafc.6b05813

9. Corkidi L., Rowland D. L., Johnson N. C., Allen E. B. 2002. Nitrogen fertilization alters the functioning of arbuscular mycorrhizas at two semiarid grasslands. Plant and Soil, 240 (2): 299-310. https://doi.org/10.1023/A:1015792204633

10. Czachor H., Charytanowicz M., Gonet S., Niewczas J., Jozefaciuk G., Lichner L. 2015. Impact of long-term mineral and organic fertilizer application on the water stability, wettability and porosity of aggregates obtained from two loamy soils. European Journal of Soil Science, 66 (3): 577-588. https://doi.org/10.1111/ejss. 12242

11. Dimoyiannis D. 2012. Wet aggregate stability as affected by excess carbonate and other soil properties. Land Degradation and Development, 23 (5): 450-455. https://doi.org/10.1002/ldr.1085

12. DuPont S. T., Culman S. W., Ferris H., Buckley D. H., Glover J. D. 2010. No-tillage conversion of harvested perennial grassland to annual cropland reduces root biomass, decreases active carbon stocks, and impacts soil biota. Agriculture, Ecosystems and Environment, 137 (1): 25-32. https://doi.org/10.1016/j.agee.2009.12.021

13. Haynes R. J., Naidu R. 1998. Influence of lime, fertilizer and manure applications on soil organic matter content and soil physical conditions: a review. Nutrient Cycling in Agroecosystems, 51 (2): 123-137. https://doi.org/10.1023/A:1009738307837

14. Jirků V., Kodešová R., Nikodem A., Mühlhanselová M., Žigová A. 2013. Temporal variability of structure and hydraulic properties of topsoil of three soil types. Geoderma, 204: 43-58. https://doi.org/10.1016/j.geoderma.2013.03.024

15. Jung J. Y., Lal R., Jastrow J. D., Tyler D. D. 2011 Nitrogenous fertilizer effects on soil structural properties under switchgrass. Agriculture, Ecosystems and Environment, 141 (1): 215-220. https://doi.org/10.1016/j.agee.2011.01.016

16. Kasper M., Buchan G. D., Mentler A., Blum W. E. H. 2009. Influence of soil tillage systems on aggregate stability and the distribution of $\mathrm{C}$ and $\mathrm{N}$ in different aggregate fractions. Soil and Tillage Research, 105 (2): 192-199. https://doi.org/10.1016/j.still.2009.08.002

17. Kemper W. D., Rosenau R. C. 1986. Aggregate stability and size distribution. Klute A. et al. (eds). Methods of soil analysis. Part I. ASA and SSSA, USA, p. 425-442.

18. Le Bissonnais Y., Arrouays D. 1997. Aggregate stability and assessment of soil crustability and erodibility. II. Application to humic loamy soils with various organic carbon contents. European Journal of Soil Science, 48 (1): 39-48. https://doi.org/10.1111/j.1365-2389.1997.tb00183.x

19. Leelamanie D. A., Liyanage T. D. 2016. Water repellent effects of manure amended soils on organic matter decomposition, $\mathrm{C}$ retention, and respired $\mathrm{CO}_{2}-\mathrm{C}$. Biologia, 71 (9): 996-1001.

https://doi.org/10.1515/biolog-2016-0127

20. Liu M. Y., Chang Q. R., Qi Y. B., Liu J., Chen T. 2014. Aggregation and soil organic carbon fractions under different land uses on the tableland of the Loess Plateau of China. Catena, 115: 19-28.

https://doi.org/10.1016/j.catena.2013.11.002

21. Nawaz M. F., Bourrie G., Trolard F. 2013. Soil compaction impact and modelling. A review. Agronomy for Sustainable Development, 33 (2): 291-309. https://doi.org/10.1007/s13593-011-0071-8

22. OECD. 2016. Organisation for Economic Co-operation and Development. Agri-environmental indicators: nutrients. http://stats.oecd.org/Index.aspx?datasetcode=AEI NUTRIENTS

23. Ortas I., Akpinar C., Lal R. 2013. Long-term impacts of organic and inorganic fertilizers on carbon sequestration in aggregates of an Entisol in Mediterranean Turkey. Soil Science, 178 (1): 12-23. https://doi.org/10.1097/SS.0b013e3182838017 
24. Reintam E., Kuht J., Loogus H., Nugis E., Trukmann K. 2005. Soil compaction and fertilisation effects on nutrient content and cellular fluid $\mathrm{pH}$ of spring barley (Hordeum vulgare L.). Agronomy Research, 3 (2): 189-202.

25. Rengasamy P., Marchuk A. 2011. Cation ratio of soil structural stability (CROSS). Soil Research, 49 (3): 280-285. https://doi.org/10.1071/SR10105

26. Sáez-Plaza P., Michałowski T., Navas M. J., Asuero A. G., Wybraniec S. 2013. An overview of the Kjeldahl method of nitrogen determination. I. Early history, chemistry of the procedure, and titrimetric finish. Critical Reviews in Analytical Chemistry, 43 (4): 178-223. https://doi.org/10.1080/10408347.2012.751786

27. Sánchez de Cima D., Tein B., Eremeev V., Luik A., Kauer K., Reintam E., Kahu G. 2016. Winter cover crop effects on soil structural stability and microbiological activity in organic farming. Biological Agriculture and Horticulture, 32 (3): 170-181. https://doi.org/10.1080/01448765.2015.1130646

28. Semenov V. M., Kogut B. M., Lukin S. M. 2014. Effect of repeated drying-wetting-freezing-thawing cycles on the active soil organic carbon pool. Eurasian Soil Science, 47 (4): 276-286. https://doi.org/10.1134/S1064229314040073

29. Sheehy J., Regina K., Alakukku L., Six J. 2015. Impact of no-till and reduced tillage on aggregation and aggregateassociated carbon in Northern European agroecosystems. Soil and Tillage Research, 150: 107-113. https://doi.org/10.1016/j.still.2015.01.015

30. Soil Survey Staff. 2014. Kellogg soil survey laboratory methods manual. Soil Survey Investigations Report No. 42, version 5.0. Burt R. et al. (eds). U.S. Department of Agriculture, Natural Resources Conservation Service, p. $279-281$

31. Suseela V., Conant R. T., Wallenstein M. D., Dukes J. S. 2012. Effects of soil moisture on the temperature sensitivity of heterotrophic respiration vary seasonally in an old-field climate change experiment. Global Change Biology, 18 (1): 336-348.

https://doi.org/10.1111/j.1365-2486.2011.02516.x

32. Tang C. S., Cui Y. J., Shi B., Tang A. M., An N. 2016. Effect of wetting-drying cycles on soil desiccation cracking behaviour. E3S Web of Conferences, 9 (12003): 1-6. https://doi.org/10.1051/e3sconf/20160912003

33. Tang J., Mo Y., Zhang J., Zhang R. 2011. Influence of biological aggregating agents associated with microbial population on soil aggregate stability. Applied Soil Ecology, 47 (3): 153-159.

https://doi.org/10.1016/j.apsoil.2011.01.001

34. Tisdall J. M., Oades J. 1982. Organic matter and waterstable aggregates in soils. European Journal of Soil Science, 33 (2): 141-163. https://doi.org/10.1111/j.1365-2389.1982.tb01755.x

35. Truman C. C., Bradford J. M., Ferris J. E. 1990. Antecedent water content and rainfall energy influence on soil aggregate breakdown. Soil Science Society of America Journal, 54 (5): 1385-1392. https://doi.org/10.2136/ sssaj1990.03615995005400050030x

36. Vorobeva L. A. 1998. Chemical analysis of soils. Moscow, Russia, 272 p. (in Russian).

37. Wang E., Cruse R. M., Chen X., Daigh A. 2012. Effects of moisture condition and freeze/thaw cycles on surface soil aggregate size distribution and stability. Canadian Journal of Soil Science, 92 (3): 529-536.

https://doi.org/10.4141/cjss2010-044

38. WRB. 2014. World Reference Base for soil resources 2014, update 2015. http://www.fao.org/3/a-i3794e.pdf

39. Zaher H., Caron J. 2008. Aggregate slaking during rapid wetting: Hydrophobicity and pore occlusion. Canadian Journal of Soil Science, 88 (1): 85-97. https://doi.org/10.4141/CJSS07021

ISSN 1392-3196 / e-ISSN 2335-8947

Zemdirbyste-Agriculture, vol. 105, No. 3 (2018), p. 195-202

DOI 10.13080/z-a.2018.105.025

\title{
Dirvožemio grumstelių stabilumas, priklausomai nuo tręšimo mèšlu ir azoto trąšomis
}

\author{
M. Are ${ }^{1}$, T. Kaart ${ }^{2}$, A. Selge ${ }^{1}$, A. Astover ${ }^{1}$, E. Reintam ${ }^{1}$ \\ ${ }^{1}$ Estijos gyvybès mokslų universiteto Žemès ūkio ir aplinkos mokslų institutas \\ ${ }^{2}$ Estijos gyvybès mokslų universiteto \\ Veterinarinès medicinos ir gyvulininkystès mokslų institutas
}

\begin{abstract}
Santrauka
Vienas svarbiausių dirvožemio sveikatingumo rodiklių yra vandenyje patvarių grumstelių stabilumas, nes jis turi įtakos dirvožemio cheminèms, biologinèms ir fizikinèsms savybėms. Be to, vandenyje patvarių grumstelių formavimasis, stabilizavimasis ir degradacija yra vieni iš sudètingiausių dirvožemyje vykstančių procesų, kuriuos sunku iki galo paaiškinti. Vandenyje patvarių grumstelių tyrimų itin trūksta Baltijos jūros regione. Siekiant geriau suprasti, kaip vyksta agregacijos procesas Estijos pedoklimatinèmis sąlygomis, smèlingo priemolio stagniame išplautžemyje 2014-2015 m. buvo atliktas tyrimas. Analizuota trejų metų bulvių ir miežių laukeliai sèjomaina (bulvès $\rightarrow$ vasariniai kviečiai $\rightarrow$ miežiai), šiaudus pašalinant iš laukelių. Tirti tręšimo azotu (N) variantai: $0,40,80,120$ ir $160 \mathrm{~kg} \mathrm{ha}^{-1}$ per metus ${ }^{-1} \mathrm{~N}$, nenaudojus ir panaudojus $40 \mathrm{Mg} \mathrm{ha}^{-1}$ fermentuoto galvijų mėšlo prieš bulvių sodinimą rudenị. Vandenyje patvarių grumstelių kiekis buvo nustatytas orasausiuose mažesniuose nei $2 \mathrm{~mm}$ skersmens dirvožemio mėginiuose drègno sijojimo aparatu. Tyrimas atskleidè neigiamą koreliaciją $(r=-0,16)$ tarp didesnių $\mathrm{N}$ normų ir vandenyje patvarių grumstelių kiekio, nepriklausomai nuo fermentuoto galvijų mėšlo naudojimo. Nors dirvožemio organinès anglies kiekis didèjo didinant $\mathrm{N}$ tręšimo normas, dèl $\mathrm{N}$ tręšimo sumažèjęs dirvožemio rūgštumas $\left(\mathrm{pH}_{\mathrm{KCl}}\right.$ lygis) greičiausiai buvo kompensuotas teigiamu dirvožemio organinės anglies poveikiu vandenyje patvarių grumstelių kiekiui. Lyginant tik su tręšimu azotu, tręšimas fermentuotu galvijų méšlu turèjo teigiamą įtaką vandenyje patvarių grumstelių kiekiui. Nors tręšimas fermentuotu galvijų mėšlu ne visada didino vandenyje patvarių grumstelių kiekị, jis turejo teigiamą ịtaką dirvožemio tankiui, organinès anglies kiekiui ir rūgštumui. Dèl sudètingų dirvožemio agregacijos procesų reikia tolesnių tyrimų.
\end{abstract}

